\title{
Surgical correction of the Midface in Craniofacial Microsomia. Part 1: a systematic review.
}

Lara S. van de Lande, BSc ${ }^{a, b}$; Britt I. Pluijmers, MD, DMDa; Cornelia J.J.M.

Caron, MD, DMDa; Eppo B. Wolvius, DDS, MD, PhDa; David J. Dunaway, CBE, FDSRCS, FRCS(plast) ${ }^{c}$; Maarten J. Koudstaal, MD, DDS, PhDa,b,c; Bonnie L. Padwa, DMD, MD

a The Dutch Craniofacial Center, Department of Oral and Maxillofacial Surgery, Erasmus University Medical Center, Sophia Children's Hospital Rotterdam, Rotterdam, The Netherlands

${ }^{b}$ Department of Plastic and Oral Surgery, Boston Children's Hospital, Boston, The United Stated of America

${ }^{\mathrm{c}}$ The Craniofacial Unit, Great Ormond Street Hospital, London, United Kingdom

Head of department: Bonnie L. Padwa, DMD, MD 
Corresponding Author Contact Information Page

Address: Britt Pluijmers, MD, DMD

Department of Oral and Maxillofacial Surgery

Erasmus University Medical Center Sophia Children's Hospital Rotterdam

's Gravendijkwal 230

3015 CE Rotterdam

Netherlands

Tel.: +31010 7033519;

Fax: +310107033098

E-mail: b.pluijmers@erasmusmc.nl 


\section{ABSTRACT}

\section{Introduction}

Mandibular reconstruction in craniofacial microsomia (CFM) has been described and reviewed at length although final results are not always (aesthetically) satisfactory due to maxillo-mandibular asymmetry, for which optimal correction techniques remain unclear. The aim of this systematic review is to provide an overview of the surgical options for maxillary correction in patients with unilateral CFM.

\section{Material and Methods}

MEDLINE/Pubmed, Embase, Cochrane and Web of Science databases were searched up to April 15, 2017. Inclusion criteria were: studies reporting patients with unilateral CFM $(n>4)$ who had maxillary correction (with/without simultaneous mandibular correction) with a minimal follow-up of 6 months. The outcome measures included type of treatment (including preceding facial procedures), type and severity of mandibular deformity (by Pruzansky-Kaban system: Types I/Ila/llb/III), asymmetry analysis method, outcome (i.e. occlusion, canting, stability, esthetic result, facial symmetry), complications and additional treatment needed.

\section{Results}

Nine studies met the inclusion criteria. Analysis showed that Le Fort I + mandibular distraction osteogenesis (LeFort+MDO) and BiMaxillary osteotomy (BiMax) were 
used for treatment, as single or multiple-stage procedures. All studies reported aesthetic and functional improvement.

\section{Conclusion}

Types I//la benefited from LeFort+MDO; Type Ilb from LeFort+MDO or BiMax; and Type III from BiMax (with $50 \%$ of cases having preceding mandibular procedures, including patient-fitted prosthesis) at a mean age of 20.2 years. Four studies recommended additional (esthetic) procedures. 


\section{KEYWORDS}

Craniofacial microsomia, hemifacial microsomia, bimaxillary osteotomy, osteotomy,

le Fort, mandibular distraction osteogenesis, systematic review 


\section{INTRODUCTION}

Craniofacial microsomia (CFM) is a congenital malformation of the derivatives of the first and second pharyngeal arches; primary involving the lower- and mid-face; resulting in a heterogeneous phenotype of facial asymmetry. (Molina et al., 1995; Granstrom et al., 1999; Caron et al., 2017) A predominantly unilateral presentation is found in $88,6 \%$ of all patients. The right-left ratio in unilateral patients is reported $1,2: 1 ;$ which is the same for the male-female ratio.(Caron et al., 2017)

The deformity is captured through several grading systems. The most recent grading system: the Phenotypic Assesment Tool - Craniofacial Microsomia (PATCFM)(Birgfeld et al., 2011) follows the Pruzansky-Kaban system in describing the malformation of the mandible. It consists of four types: Type I is a normally shaped but small mandible; Type Ila is a small and abnormally shaped mandibular ramus whereas Type Ilb is a small, abnormally shaped and located mandibular ramus and temporo-mandibular joint (TMJ); and Type III describes an absent ramus, condyle and TMJ.(Kaban et al., 1986) Deviation of the mandible upwards and towards the affected side is observed in patients with CFM and is associated with canting of the occlusal plane,(Grayson et al., 1983) and facial asymmetry. A critical step in achieving better facial skeletal harmony is to restore the maxillo-mandibular symmetry.

Mandibular reconstruction in patients with CFM has been described and reviewed at length, showing that the outcome of treatment is not so much treatment- 
dependent, but patient and severity dependent.(Pluijmers et al., 2014) Some studies recommend the use of mandibular distraction osteogenesis (MDO) - with or without previous bone grafts - for correction of the mandiblular deformity.(Pluijmers et al., 2014) However, the final results of MDO are not always satisfactory due to canting of the occlusal plane and complete three-dimensional facial and occlusal symmetry is not always obtained.(Polley et al., 1997; Nagy et al., 2009)

The optimal choice of technique to correct the maxillo-mandibular asymmetry in patients with CFM remains unclear. Several techniques have been used to obtain a medial rotation and elongation, such as a Le Fort I osteotomy with simultaneous mandibular distraction osteogenesis (LeFort+MDO)(Molina, 1999) and bimaxillary rotational osteotomies: a Le Fort I osteotomy with a bilateral sagittal split osteotomy of the mandible (BiMax).(Obwegeser, 1969)

The aim of this study is to investigate and create an overview of the surgical treatments for surgical correction of the maxilla (with or without simultaneous correction of the mandible) to correct the asymmetry in patients with CFM. Secondary outcomes were relapse, number of corrections, timing of the procedures and complications.

\section{MATERIAL AND METHODS}

The PRISMA statement (Moher et al., 2011) was used as guideline for this structured review of the literature. 
Search strategy

A comprehensive literature search was conducted on surgical correction of the maxilla in patients with unilateral CFM up to April 15, 2017 within the databases MEDLINE/Pubmed, Embase, Cochrane and Web of Science. The heading sequence ('jaw malformation'/de OR 'Goldenhar syndrome'/de OR 'hemifacial microsomia'/exp OR 'maxilla hypoplasia'/de OR 'face asymmetry'/exp OR 'craniofacial malformation'/de OR (maxilla/exp AND 'bone defect'/de) OR (((hemifac* OR craniofac*) NEAR/3 microsom*) OR cfm OR ((face OR facial) NEAR/3 asymmetr*) OR Goldenhar OR ((maxill* OR premaxill* OR craniofac* OR craniomaxillofac*) NEAR/3 (malform* OR deform* OR defect* OR deficien* OR hypoplas* OR asymmetr* OR syndrom*))):ab,ti) AND (osteotomy/de OR 'maxilla osteotomy'/de OR 'bone transplantation'/de OR 'bone graft'/de OR 'bone allograft'/de OR 'distraction osteogenesis'/de OR orthodontics/de OR 'orthodontic device'/exp OR 'orthognathic surgery'/exp OR 'bone remodeling'/exp OR (((midface OR 'mid face' OR maxill $\left.{ }^{\star}\right)$ NEAR/3 (reconstruct $\left.{ }^{\star}\right)$ ) OR osteotom* OR bimax* OR sarme OR ((Surgical* OR operat* ${ }^{\star}$ NEAR/3 Maxill* NEAR/3 Expan*) OR (bone NEAR/3 graft ${ }^{\star}$ ) OR allograft* OR (distract* NEAR/3 osteogenes*) OR orthodonti* OR remodel ${ }^{\star}$ OR reposition* OR (surg* NEAR/3 correct*) OR 'le fort' OR lefort OR orthognath*):ab,ti) AND [english]/lim NOT ([animals]/lim NOT [humans]/lim) was selected and studies meeting the inclusion criteria were included.

$\underline{\text { Inclusion criteria }}$ 
Two authors (LSvdL and BIP) independently selected prospective and retrospective studies meeting the inclusion criteria: studies reporting patients with unilateral CFM $(n>4)$ who had correction of the maxilla (with or without simultaneous mandibular correction) with a minimal follow-up of 6 months. Furthermore a language restriction was applied: only articles written in English were selected.

\section{Data extraction and analysis}

LSvdL and BIP independently assessed the titles and abstracts of all papers. Abstracts of scientific meetings, reviews and duplicates were excluded. Subsequently, the authors reviewed the full text of the selected studies for final inclusion. The reference lists of the included studies were hand-searched for relevant studies that were not included initially using the aforementioned inclusion criteria. Studies reporting a heterogeneous study population and/or studies reporting exclusively bilateral cases were excluded due to possible bias; studies with fewer than 4 patients and studies with a follow-up time of less than 6 months were excluded for expected low level of evidence.(Altman, 1980) Authors of studies were contacted by email when the study did not report information on preceding asymmetry corrective surgery. When this information could not be collected, the study was excluded due to possible bias. Using the Oxford Centre for Evidence-Based Medicine (OCEBM) criteria, the studies were graded on quality of evidence.(Durieux et al., 2013) Data was collected and tabulated, if available, on: number of CFM patients who had maxillary correction (with or without simultaneous mandibular correction), number of CFM patients with preceding mandibular surgery, type of 
preceding mandibular surgery, classification of mandibular type (by the PruzanskyKaban or Pruzansky system), type of surgical treatment to correct the maxilla (and mandible), mean age at time of surgical treatment, analysis method of the asymmetry and timing of the analysis, maxillary (and mandibular) movement, outcome (increase or decrease in asymmetry, including occlusal plane and residual cant, and patients' satisfaction), follow-up length, number and kind of complications, and number and type of additional treatments performed or recommended.

\section{RESULTS}

The literature search yielded 5,509 publications. Screening of reference lists of the included articles did not result in any additional articles. After applying the selection criteria, 179 publications were read in full text, of which 16 were initially included. Nine papers were excluded for lack of data on preceding mandibular correction, leaving 7 studies for inclusion. (Fig. 1) (Monasterio et al., 1997; Balaji, 2010; Ohtani et al., 2012; Wolford et al., 2012; Fattah et al., 2014; Luo et al., 2016; Liu et al., 2017)

\section{Study characteristics and quality}

Included studies were prospective $(n=2)$ and retrospective case series $(n=5)$. All studies met the OCEBM criteria for level IV evidence. A meta-analysis was not conducted due to the heterogeneity of the reported outcomes. A total of 57 patients with unilateral CFM had maxillary correction. In all cases the mandibular asymmetry was treated simultaneously at a mean age of 20.2 years (range: 12.0 - 
26.0 years). The mean follow-up time was 24.8 months (range: $6.0-75.0$ months). (Tables 1 and 2)

$\underline{\text { Treatment and classification }}$

Two different types of treatment were used in the included studies: 1) bimaxillary osteotomy (BiMax), including one study (Wolford et al., 2012) using mandibular advancement with a patient-fitted total joint prosthesis on the affected side with a contralateral mandibular ramus sagittal split osteotomy and maxillary osteotomies in a counterclockwise direction; and 2) Le Fort I + mandibular distraction osteogenesis (LeFort +MDO), including one study (Liu et al., 2017) using LeFort+MDO followed by a sagittal split osteotomy - which was performed in a second procedure - on the unaffected side as part of a 2-step procedure.

Surgical correction of exclusively the maxilla was not reported. LeFort+MDO was analyzed in 4 studies and BiMax in 3 studies, respectively reporting 37 cases with LeFort+MDO at a mean age of 19.9 years (range: $12.0-26.0$ years) and 20 cases with BiMax at a mean age of 19.7 years (range: 18.0 - 23.5 years). No preceding asymmetry corrections or procedures to create adequate bone stock prior to LeFort+MDO were reported. In one study an extra-orally placed distractor was used, one study described the use of an intra-orally placed distractor; one study reported on both extra-orally and intra-orally placed distractors and one study did not comment on the type of distractor. 
Of the cases treated with BiMax, $50 \%$ had undergone one or multiple (up to 12) attempts for asymmetry correction prior to the study, such as mandibular distraction osteogenesis (MDO), rib graft, tibia graft and sternoclavicular graft. (Tables 2 and 4 )

The Pruzansky classification system (Pruzansky, 1969) (composed of Types I, II and III) and Pruzansky-Kaban classification system(Kaban et al., 1986) (composed of Types I, Ila, IIb and III) were used for grading the mandibular deformity in patients with CFM (Table 3). The majority of the included patients had a Type I mandible ( $n=19)$, followed by Type Ila $(n=12)$, Type Ilb $(n=10)$, Type III $(n=9)$ and a group of Type I and Type II ( $n=7)$. Monasterio et al. 1997(Monasterio et al., 1997) tabulated Type I and Type II as one group $(n=7)$ due to the low number of patients available. LeFort+MDO was used to treat Type I (84\%), Type Ila (75\%) and Type Ilb (50\%). No patients with Type III were treated with LeFort+MDO. BiMax was used to treat Type III (100\%), Type Ilb (50\%), Type Ila (25\%) and Type I (16\%). (Table 4)

\section{Facial asymmetry analysis methodology}

Cephalometric analysis was used in all studies pre- and post-operatively. Post-operatively, Fattah, A. Y. et al. 2014(Fattah et al., 2014) and Luo, E. et al 2016(Luo et al., 2016) repeated the cephalometric analysis immediately posttreatment. All 7 studies repeated the cephalometric analysis after 6 months or more. Four studies (Balaji, 2010; Ohtani et al., 2012; Luo et al., 2016; Liu et al., 
2017) used additional clinical facial photographs to analyze the facial (a)symmetry. (Table 5)

Outcome 0-7 days post-treatment

Most studies showed improved facial symmetry and aesthetically satisfactory outcomes, based on the surgeons' and/or patients' opinion.(Monasterio et al., 1997; Balaji, 2010; Wolford et al., 2012; Fattah et al., 2014) The maxillary downward movement varied from 0 to $7.5 \mathrm{~mm}$ with BiMax(Wolford et al., 2012; Fattah et al., 2014) and from 4.0 to $7.0 \mathrm{~mm}$ with LeFort+MDO.(Monasterio et al., 1997) When LeFort+MDO was used, Balaji, S. M. et al. 2010, overcorrected with 2$3 \mathrm{~mm}$ on the predicted distraction length (Balaji, 2010) and Monasterio, F. O. et al. 1997, reported predicted overcorrection, although the amount of overcorrection was not mentioned.(Monasterio et al., 1997) There was no data available on overcorrection when BiMax was used. Balaji, S. M. et al. 2010, reported mild overcorrection in the first week post-treatment. All studies showed improved leveling of the occlusal plane and four studies measured a slight residual cant of a maximum of 2.3 degrees. (Table 6) Only one study reported relapse (Fattah et al., 2014). Wolford, L. M. et al. 2012 showed significant improvement on the following parameters with a subjective analysis: rating on pain, jaw movement, diet ability and level of total disability, however limitation in jaw function retained. (Wolford et al., 2012) (Table 7)

\section{$\underline{\text { Complications }}$}


Wolford, L. M. et al. 2012, reported fibrosis of TMJ in a patient treated with BiMax, who also had a TMJ reconstruction. (Wolford et al., 2012) This patient had undergone 12 previous procedures prior to the definitive BiMax operation. A total of six patients had temporary lower lip paresis that resolved within 3-6 months without any treatment. Luo, E. et al 2016 , reported two patients with pin tract infection of the distraction device and loosening of the pins, which was adequately treated with antibiotics. (Luo et al., 2016) In one study no complications were encountered.(Monasterio et al., 1997) The three other studies did not comment on complications (Balaji, 2010; Ohtani et al., 2012; Fattah et al., 2014).(Table 7)

\section{$\underline{\text { Outcome }}$}

The follow-up ranged from 6-75 months. Overall, the follow-up showed satisfactory results: aesthetic and functional improvement, with a minimal number of patients having reported relapse. A few cases had overcorrection. Most studies advised a simultaneous maxillo-mandibular reconstruction with orthodontic pretreatment at time of skeletal maturity or permanent dentition. In the more severe cases of CFM (Type IIb and III mandibular deformities) procedures were recommended prior to simultaneous maxillo-mandibular surgery, including a patient-fitted total joint prosthesis to construct the TMJ and the use of a (rib/tibia/ sternoclavicular) graft to create more bone stock and/or construct a TMJ.(Bezrukov et al., 1988; Ohtani et al., 2012; Wolford et al., 2012) Two studies recommended a two-step procedure: Ohtani, J. et al. 2012, recommended creating bone stock with the use of a rib graft prior to Bimax (Ohtani et al., 2012) and Liu H. et al 2017, 
recommended a LeFort+MDO procedure with additional SSRO - as a secondary procedure - on the unaffected side and if needed, a genioplasty performed during the second procedure. (Liu et al., 2017) (Table 8)

Wolford, L. M. et al. 2012, analyzed patients' satisfaction using a survey post-reconstruction and reported less pain, better jaw function and better psychological function (e.g. less emotional stress). (Wolford et al., 2012)

\section{Additional surgical procedures}

Four studies recommended additional (aesthetical) procedures including genioplasty, rhinoplasty, artificial or autologous (fat) fillers, free flaps and alloplastic implants - either in the same setting or as a secondary operation.(Monasterio et al., 1997; Ohtani et al., 2012; Wolford et al., 2012; Fattah et al., 2014) (Table 9)

\section{DISCUSSION}

A systematic review was conducted of available English literature addressing surgical correction of the maxilla (with or without simultaneous correction of the mandible) in patients with unilateral CFM. The literature showed that both LeFort+MDO and BiMax were used as techniques for correction of the asymmetric midface. Isolated maxillary correction was not reported. This does make sense from a clinical perspective as this would disrupt the occlusion. All studies used the mandibular CFM classification system by Pruzansky (-Kaban) and showed that: Types I and Ila had LeFort+MDO; Type Ilb could either be treated 
with BiMax or LeFort+MDO; and Type III with BiMax. The patients treated with BiMax benefited from this treatment with or without a preceding procedure, which included alloplastic or autologous grafts. None of the patients with a Type I mandible had a procedure preceding facial asymmetry correction, but the majority of the patients with Types IIa, Ilb and III had asymmetry corrections prior to the study, including mandibular distraction osteogenesis (MDO), rib graft, tibia graft and sternoclavicular graft. The literature shows that BiMax is used in more severe cases and that the majority of these cases undergo (multiple) operations prior to the BiMax procedure, suggesting that patients with more severe CFM might benefit from a multi-stage treatment approach. Since no data was available on the timing of the corrective operations prior to BiMax, no conclusions can be drawn on the best timing for the first attempt at correction. However, some studies recommend postponing intervention, if possible, until skeletal maturity. The data from this study is in agreement with previous systematic reviews(Mommaerts et al., 2002; Pluijmers et al., 2014) which suggest delaying mandibular reconstruction until the permanent dentition, or even skeletal maturity if there are no pressing functional and/or psychosocial problems. Several studies state that there is no evidence supporting the effectiveness of early asymmetry correction in patients with CFM.(Nagy et al., 2009) Nevertheless, there are definite indications for early surgery: functional impairments (i.e. airway, swallowing, mastication, speech and psychosocial) should dictate the timing of surgical intervention; and patients with respiratory obstruction (i.e. breathing issues and sleep apnea, feeding and speech difficulties and/or emotional distress)(Murray et al., 1984) should be candidates for 
early interventions.(Wolford et al., 2001a, b) However, even when delaying correction until permanent dentition, six out of seven studies in this systematic review recommended additional (aesthetic) surgery. Therefore, patients and their caregivers should be made aware that treating the deformities caused by CFM is a long process and that, in the long term, additional procedures may be needed.

Information on preceding corrective surgery in CFM patients is essential to analyze the outcome of the used treatment; a severely affected CFM patient with multiple attempts for correction might have a different outcome than a severely affected CFM patient without previous correction. Initially, 16 studies were included, however, nine studies were excluded for lack of data on preceding corrective surgery. Therefore, a limited number of patients were available for analyses.

Fifty percent of the patients treated with BiMax had undergone previous asymmetry correction. Unfortunately, as sparse information regarding the type of treatment prior to BiMax was reported, there was no baseline data on the degree of canting, (mal)occlusion and the number of millimeters of distraction or the length of graft used prior to BiMax. Therefore, it is unclear what degree of severity of asymmetry was present at the time of surgery. Furthermore, the degree of canting of the maxilla was not reported. It is unclear if the degree of maxillary canting is proportional to the severity of the mandibular asymmetry (graded by the Pruzansky(-Kaban) classification). Thus, it is impossible to compare the reported patients and their treatments. Therefore, we suggest a study designed to analyze 
the maxillary canting of patients with CFM. The authors of this study hypothesize a positive correlation of mandibular hypoplasia and the degree of maxillary canting. If there is a correlation between maxillary canting and the Pruzansky-Kaban classification, a more profound recommendation for treatment could be provided for the correction of the maxillo-mandibular asymmetry.

The mean follow-up time was 28.3 months (range: 6.0-75.0 months). Most studies reported a satisfactory outcome in the long term, but the majority lacked statistical evidence. LeFort+MDO had a mean follow-up time of 9.2 months compared to a BiMax follow-up time of 45.9 months. These enormous differences in follow-up time make comparing between the two techniques impossible. No significant relapse was documented with either technique. Overcorrection of 2-3 millimeters resolved into a more symmetrical outcome in most cases. The occlusal cant was not always fully corrected as four studies showed a residual cant with a maximum of 2.31 degrees. However, Padwa, B.L. et al. 1997, showed that an occlusal cant must be more than 4 degrees to be visually notable.(Padwa et al., 1997)

Furthermore, the authors of this work advocate to aim for some canting in relation to the soft tissue asymmetry most often present due to soft tissue deficiency and facial nerve dysfunction. This means not completely correcting the skeletal asymmetry and leaving some occlusal cant, so, when the face is animating, the soft tissue cant is in line with the occlusal cant. Correcting the bony chin in these cases corrects for the passive asymmetrical face. This way, both in 
rest and during animation, the patients tend to have the best harmony between soft and hard tissues, thus resulting in the best achievable (esthetic) outcome.

It seems impossible to predict which patients would benefit from overcorrection and which patients would not. In a study on maxillo-mandibular reconstruction of class III malocclusion, $20 \%$ of the patients had a relapse of more than 2 millimeters, suggesting that an overcorrection of 2 millimeters is advisable.(Proffit et al., 1991) However, no data was available on the predictable factors for the need of overcorrection. Even though facial analyses were performed pre- and post-operative, specificity and sensitivity of these measurements may be questioned since there was no use of modern measurements(Akhil et al., 2015) such as 3D analysis.

None of the included studies used computer aided surgical planning for the correction of the maxillo-mandibular complex. The use of 3D computer-aideddesign and computer-aided-manufacturing principles are described as an accurate and reliable method in the diagnosis, treatment planning, and designing of cutting guides that optimize surgical correction in a small number of patients with hemimandibular hyperplasia and Class III malocclusion (Hatamleh et al., 2016; Hatamleh et al., 2017) Moreover, as recent studies suggest that asymmetry occurs from skull base and on, the mandible and maxilla seen as a continuum part of this.(Tuin et al., 2015; Caron et al., 2017) It could aid in these complex cases in which the standardized cephalometry does not apply. A Case report on the correction of a patient with CFM with the use of computer assisted orthognatic 
surgical protocol confirms the clinical feasibility.(Vale et al., 2016) However, no large studies exist and more research is needed to confirm the advantages of computer aided surgical planning.

In the modern era, treatment benefits are based on multiple factors, including objective analyses such as 3D measurement techniques, skeletal and/or soft tissue analysis, complications, opinion of the physician, and satisfaction of the patient (and his/her caregivers). However, only one study reported results based on the patient's opinion. In the future, a study on quality of life and other outcome measurements could be useful to truly answer the results of the treatment and the needs of these patients. A global workgroup focusing on patient-reported outcomes has presented a minimal set of outcomes for CFM patients in 2015. (The International Consortium for Health Outcomes Measurement (ICHOM), n.d.)

The lack of information on aforementioned factors makes it impossible to truly answer the question of which treatment and timing would definitely benefit these patients to correct the maxilla and restore the facial harmony. Therefore, the authors started collecting retrospective data at four major craniofacial centers on all facial corrective treatments, their outcomes and complications, and initiated a study on 3D-measurement analyses and a study on maxillary canting in patients with CFM.

CONCLUSION 
This systematic review shows that surgical correction of the maxilla was performed simultaneously with correction of the mandible in all reported patients at a mean age of 20.2 years in a total of 57 patients with unilateral CFM. Severity of the mandibular deformity was graded by the Pruzansky (-Kaban) classification and showed that Types I and Ila would benefit from LeFort+MDO; Type IIb from LeFort+MDO or BiMax; and Type III from BiMax (of which $50 \%$ of the cases had preceding mandibular surgery, including the use of a patient-fitted prosthesis), either as a one-step procedure, or as part of a two-step treatment algorithm. However, due to lack of data, no hard conclusions can be drawn on the ideal surgical treatment to correct the asymmetry and the timing in patients with CFM. Moreover, additional (aesthetical) procedures were frequently suggested to achieve the desired end-result. 
Acknowledgements and conflicts of interest statement

Acknowledgements

We thank W. Bramer, biomedical information specialist of Erasmus MC, for his assistance with the literature search.

Funding statement:

This research did not receive any specific grant from funding agencies in the public, commercial, or not-for-profit sectors.

Competing Interests Statement:

There are no conflicts of interest in the materials or subject matter dealt with in the manuscript.

Contributorship Statement:

All authors made substantial contributions to conception and design, acquisition of data, or analysis and interpretation of data. All authors were involved in drafting the article or critically revising it for important intellectual content. And, finally, all authors approved of the version to be published. 


\section{REFERENCES}

Akhil G, Senthil Kumar KP, Raja S, Janardhanan K: Three-dimensional assessment of facial asymmetry: A systematic review. Journal of pharmacy \& bioallied sciences 7:S433$437,2015$.

Altman DG: Statistics and ethics in medical research: III How large a sample? Br Med J 281:1336-1338, 1980.

Balaji SM: Change of lip and occlusal cant after simultaneous maxillary and mandibular distraction osteogenesis in hemifacial microsomia. J Maxillofac Oral Surg 9:344-349, 2010. Bezrukov VM, Plotnikov NA, Gun'ko VI, Babayev TA, Nikitin AA: Surgical correction of deformation of the facial skeleton in patients with hemifacial microsomia. ACTA CHIR PLAST 30:202-214, 1988.

Birgfeld CB, Luquetti DV, Gougoutas AJ, Bartlett SP, Low DW, Sie KC, Evans KN, Heike CL: A phenotypic assessment tool for craniofacial microsomia. Plast Reconstr Surg 127:313-320, 2011.

Caron C, Pluijmers BI, Wolvius EB, Looman CWN, Bulstrode N, Evans RD, Ayliffe P, Mulliken JB, Dunaway D, Padwa B, Koudstaal MJ: Craniofacial and extracraniofacial anomalies in craniofacial mlcrosomia: A multicenter study of 755 patients. J Craniomaxillofac Surg 45:1302-1310, 2017.

Durieux N, Vandenput S, Pasleau F: [OCEBM levels of evidence system] Medecine factuelle: la hierarchisation des preuves par le Centre for Evidence-Based Medicine d'oOford. Rev Med Liege 68:644-649, 2013.

Fattah AY, Caro C, Khechoyan DY, Tompson B, Forrest CR, Phillips JH: Cephalometric outcomes of orthognathic surgery in hemifacial microsomia. J Craniofac Surg 25:1734$1739,2014$. 
Granstrom G, Jacobsson C: First and second branchial arch syndrome: aspects on the embryogenesis, elucidations, and rehabilitation using the osseointegration concept. Clin Implant Dent Relat Res 1:59-69, 1999.

Grayson BH, Boral S, Eisig S, Kolber A, McCarthy JG: Unilateral craniofacial microsomia.

Part I. Mandibular analysis. Am J Orthod 84:225-230, 1983.

Hatamleh M, Turner C, Bhamrah G, Mack G, Osher J: Improved Virtual Planning for Bimaxillary Orthognathic Surgery. J Craniofac Surg 27:e568-573, 2016.

Hatamleh MM, Yeung E, Osher J, Huppa C: Novel Treatment Planning of Hemimandibular Hyperplasia by the Use of Three-Dimensional Computer-Aided-Design and ComputerAided-Manufacturing Technologies. J Craniofac Surg 28:764-767, 2017.

Kaban LB, Moses MH, Mulliken JB: Correction of hemifacial microsomia in the growing child: a follow-up study. Cleft Palate J 23 Suppl 1:50-52, 1986.

Liu H, Zhang X, Liu L, Chen Q, Shao J, Luo E: Combined Bimaxillary Distraction Osteogenesis Associated with Orthognathic Surgery for Hemifacial Microsomia in Adults. Aesthetic plastic surgery 2017.

Luo E, Yang SM, Du W, Chen QM, Liao CH, Fei W, Hu J: Bimaxillary Orthognathic Approach to Correct Skeletal Facial Asymmetry of Hemifacial Microsomia in Adults. Aesthetic plastic surgery 40:400-409, 2016.

Moher D, Altman DG, Liberati A, Tetzlaff J: PRISMA statement. Epidemiology 22:128author, 2011.

Molina F: Combined maxillary and mandibular distraction osteogenesis. Semin Orthod 5:41-45, 1999.

Molina F, Monasterio FO: Mandibular Elongation and Remodeling by Distraction - a Farewell to Major Osteotomies. Plastic and Reconstructive Surgery 96:825-840, 1995. 
Mommaerts MY, Nagy K: Is early osteodistraction a solution for the ascending ramus compartment in hemifacial microsomia? A literature study. J Cranio-Maxillofac Surg 30:201-207, 2002.

Monasterio FO, Molina F, Andrade L, Rodriguez C, Arregui JS: Simultaneous mandibular and maxillary distraction in hemifacial microsomia in adults: Avoiding occlusal disasters. PLAST RECONSTR SURG 100:852-861, 1997.

Murray JE, Kaban LB, Mulliken JB: Analysis and treatment of hemifacial microsomia. PLAST RECONSTR SURG 74:186-199, 1984.

Nagy K, Kuijpers-Jagtman AM: No Evidence for Long-Term Effectiveness of Early Osteodistraction in Hemifacial Microsomia 'Outcomes Article'. Plastic and ... 2009. Obwegeser HL: Surgical correction of small or retrodisplaced maxillae. The "dish-face" deformity. Plast Reconstr Surg 43:351-365, 1969.

Ohtani J, Hoffman WY, Vargervik K, Oberoi S: Team management and treatment outcomes for patients with hemifacial microsomia. Am J Orthod Dentofacial Orthop 141:S74-S81, 2012.

Padwa BL, Kaiser MO, Kaban LB: Occlusal cant in the frontal plane as a reflection of facial asymmetry. J ORAL MAXILLOFAC SURG 55:811-817, 1997.

Pluijmers BI, Caron CJJM, Dunaway DJ, Wolvius EB, Koudstaal MJ: Mandibular reconstruction in the growing patient with unilateral craniofacial microsomia: A systematic review. Int J Oral Maxillofac Surg 43:286-295, 2014.

Polley JW, Figueroa AA: Distraction osteogenesis: Its application in severe mandibular deformities in hemifacial microsomia. J CRANIOFAC SURG 8:422-430, 1997.

Proffit WR, Phillips C, Turvey TA: Stability after surgical-orthodontic corrective of skeletal Class III malocclusion. 3. Combined maxillary and mandibular procedures. Int J Adult Orthodon Orthognath Surg 6:211-225, 1991. 
Pruzansky S: Not all dwarfed mandibles are alike. Birth Defects Orig Artic Ser 5:120-129, 1969.

The International Consortium for Health Outcomes Measurement (ICHOM). n.d.

Tuin AJ, Tahiri Y, Paine KM, Paliga JT, Taylor JA, Bartlett SP: Clarifying the relationships among the different features of the OMENS+ classification in craniofacial microsomia.

Plast Reconstr Surg 135:149e-156e, 2015.

Vale F, Scherzberg J, Cavaleiro J, Sanz D, Caramelo F, Malo L, Marcelino JP: 3D virtual planning in orthognathic surgery and CAD/CAM surgical splints generation in one patient with craniofacial microsomia: a case report. Dental Press J Orthod 21:89-100, 2016.

Wolford LM, Bourland TC, Odrigues D, Perez DE, Limoeiro E: Successful reconstruction of nongrowing hemifacial microsomia patients with unilateral temporomandibular joint total joint prosthesis and orthognathic surgery. J Oral Maxillofac Surg 70:2835-2853, 2012. Wolford LM, Karras SC, Mehra P: Considerations for orthognathic surgery during growth, part 1: mandibular deformities. Am J Orthod Dentofacial Orthop 119:95-101, 2001a. Wolford LM, Karras SC, Mehra P: Considerations for orthognathic surgery during growth, part 2: maxillary deformities. Am J Orthod Dentofacial Orthop 119:102-105, 2001b. 
TABLES

\begin{tabular}{|c|c|c|c|c|c|c|c|}
\hline Citation & $\begin{array}{l}\text { OCEBM } \\
\text { level of } \\
\text { evidence }\end{array}$ & Methodology & $\begin{array}{c}\text { No. of } \\
\text { patients }\end{array}$ & $\begin{array}{l}\text { Surgical } \\
\text { treatment }\end{array}$ & $\begin{array}{c}\text { No. of } \\
\text { preceding } \\
\text { mandibular } \\
\text { surgery (\%) }\end{array}$ & $\begin{array}{c}\text { Mean } \\
\text { age at } \\
\text { surgery, } \\
\text { years }\end{array}$ & $\begin{array}{c}\text { Mean } \\
\text { follow- } \\
\text { up time, } \\
\text { months }\end{array}$ \\
\hline $\begin{array}{l}\text { Liu, H. et al } \\
2017 \text { (Liu et al., } \\
2017)\end{array}$ & 4 & $\begin{array}{c}\text { Retrospective } \\
\text { CS }\end{array}$ & 12 & LeFort+MDO $^{\alpha}$ & $0(0 \%)$ & 22.4 & 43.4 \\
\hline $\begin{array}{l}\text { Luo, E. et al } \\
2016 \text { (Luo et al., } \\
2016)\end{array}$ & 4 & $\begin{array}{c}\text { Retrospective } \\
\text { CS }\end{array}$ & 7 & LeFort+MDO & $0(0 \%)$ & 13.7 & 58.8 \\
\hline $\begin{array}{c}\text { Fattah, A. Y. } \\
\text { et al.2014 } \\
\text { (Fattah et al., 2014) }\end{array}$ & 4 & $\begin{array}{c}\text { Retrospective } \\
\text { CS }\end{array}$ & 8 & BiMax & $2(25.0 \%)$ & 18.0 & 38.4 \\
\hline $\begin{array}{l}\text { Wolford, L. } \\
\text { M. et al. } \\
\text { 2012 (Wolford et } \\
\text { al., 2012) }\end{array}$ & 4 & $\begin{array}{l}\text { Prospective } \\
\text { CS }\end{array}$ & 6 & $\mathrm{BiMax}^{\beta}$ & $4(67.0 \%)$ & 23.5 & 75.0 \\
\hline $\begin{array}{l}\text { Ohtani, J. et } \\
\text { al. } 2012^{\text {(Ohtani }} \\
\text { et al., 2012) }\end{array}$ & 4 & $\begin{array}{c}\text { Retrospective } \\
\text { CS }\end{array}$ & 6 & BiMax & $4(66.6 \%)$ & 18.1 & 12.0 \\
\hline $\begin{array}{l}\text { Balaji, S. M. } \\
\text { et al. } \\
2010^{\text {(Balaji, }} \\
\text { 2010) }\end{array}$ & 4 & $\begin{array}{c}\text { Retrospective } \\
\text { CS }\end{array}$ & 11 & LeFort+MDO & $0(0 \%)$ & 21.8 & 6.0 \\
\hline $\begin{array}{l}\text { Monasterio, } \\
\text { F. O. et al. } \\
1997^{\text {(Monasterio }} \\
\text { et al., 1997) }\end{array}$ & 4 & $\begin{array}{c}\text { Prospective } \\
\text { CS }\end{array}$ & 7 & LeFort+MDO & $0(0 \%)$ & 19.0 & 7.0 \\
\hline
\end{tabular}

Table 1. Overview of included studies.

OCEBM: Oxford Centre for Evidence-Based Medicine; CS: Case Series; LeFort+MDO: Le Fort I + mandibular distraction osteogenesis; BiMax: BiMaxillary osteotomy. ${ }^{\alpha}$ Followed by a sagittal split osteotomy on the unaffected side as a secondary surgery; ${ }^{\beta}$ Using a patient-fitted total joint prosthesis and mandibular 
advancement on affected side

\begin{tabular}{|c|c|c|c|c|c|}
\hline Treatment & $\begin{array}{c}\text { No. of } \\
\text { patients }\end{array}$ & $\begin{array}{c}\text { No. of } \\
\text { studies }\end{array}$ & $\begin{array}{c}\text { Mean age, } \\
\text { years } \\
\text { (range) }\end{array}$ & $\begin{array}{c}\text { Mean follow-up } \\
\text { time, months } \\
\text { (range) }\end{array}$ & $\begin{array}{c}\text { No. of } \\
\text { preceding } \\
\text { mandibular } \\
\text { surgery(\%) }\end{array}$ \\
\hline LeFort+MDO & 37 & 4 & $\begin{array}{c}19.9 \\
(12.0-26.0)\end{array}$ & $\begin{array}{c}28.3 \\
(6.0-58.8)\end{array}$ & $0(0 \%)$ \\
\hline BiMax & 20 & 3 & $\begin{array}{c}19.7 \\
(18.0-23.5)\end{array}$ & $\begin{array}{c}41.5 \\
(12.0-75.0)\end{array}$ & $10(50 \%)$ \\
\hline Total & $\mathbf{5 7}$ & $\mathbf{7}$ & $\begin{array}{c}\mathbf{2 0 . 2} \\
(\mathbf{1 2 . 0 - 2 6 . 0 )}\end{array}$ & $\begin{array}{c}\mathbf{2 4 . 8} \\
\mathbf{( 6 . 0 - 7 5 . 0 )}\end{array}$ & $\mathbf{1 0 ( 1 7 . 5 \% )}$ \\
\hline
\end{tabular}

Table 2. Overview of treatment characteristics

LeFort+MDO: Le Fort I + mandibular distraction osteogenesis; BiMax: BiMaxillary osteotomy. 


\begin{tabular}{|c|c|c|c|c|}
\hline Citation & Therapy & $\begin{array}{c}\text { Classificatio } \\
\mathbf{n}\end{array}$ & $\begin{array}{l}\text { Classification type } \\
\text { (n) }\end{array}$ & $\begin{array}{l}\text { No. of } \\
\text { preceding } \\
\text { mandibular } \\
\text { surgery (\%) }\end{array}$ \\
\hline Liu, H. et al 2017(Liu et al., 2017) & $\begin{array}{c}\text { LeFort+MDO } \\
\alpha\end{array}$ & $\begin{array}{l}\text { Pruzansky- } \\
\text { Kaban }\end{array}$ & Type I (5); Type Ila (7) & $0(0 \%)$ \\
\hline $\begin{array}{l}\text { Luo, E. et al 2016 (Luo et al., } \\
\text { 2016) }\end{array}$ & LeFort+MDO & $\begin{array}{l}\text { Pruzansky- } \\
\text { Kaban }\end{array}$ & $\begin{array}{c}\text { Type Ila (2); Type Ilb } \\
\text { (5) }\end{array}$ & $0(0 \%)$ \\
\hline $\begin{array}{l}\text { Fattah, A. Y. et al. 2014(Fattah } \\
\text { et al., 2014) }\end{array}$ & BiMax & $\begin{array}{l}\text { Pruzansky- } \\
\text { Kaban }\end{array}$ & $\begin{array}{c}\text { Type I (1); Type Ila (1) } \\
\text { Type IIb (4); Type III } \\
\text { (2) }\end{array}$ & $2(25.0 \%)^{Y}$ \\
\hline $\begin{array}{l}\text { Wolford, L. M. et al. } \\
2012^{\text {(Wolford et al., 2012) }}\end{array}$ & $\operatorname{BiMax}^{\beta}$ & $\begin{array}{l}\text { Pruzansky- } \\
\text { Kaban }\end{array}$ & $\begin{array}{c}\text { Type IIb (1); Type III } \\
\text { (5) }\end{array}$ & $4(67.0 \%)^{\beta}$ \\
\hline $\begin{array}{l}\text { Ohtani, J. et al. 2012 (Ohtani et } \\
\text { al., 2012) }\end{array}$ & BiMax & Pruzansky & $\begin{array}{c}\text { Type I (2); Type II (2); } \\
\text { Type III (2) }\end{array}$ & $4(66.6 \%)^{Y}$ \\
\hline $\begin{array}{l}\text { Balaji, S. M. et al. } 2010^{\text {(Balaji, }} \\
\text { 2010) }\end{array}$ & LeFort+MDO & Pruzansky & Type I (11) & $0(0 \%)$ \\
\hline $\begin{array}{l}\text { Monasterio, F. O. et al. } \\
\text { 1997(Monasterio et al., 1997) }\end{array}$ & LeFort+MDO & Pruzansky & Type I; Type II & $0(0 \%)$ \\
\hline
\end{tabular}

Table 3. Overview of classifications and used procedures

LeFort+MDO: Le Fort I + mandibular distraction osteogenesis; BiMax: BiMaxillary osteotomy. ${ }^{a}$ Followed by a sagittal split osteotomy on the unaffected side as a secondary surgery; ${ }^{\beta}$ Using a patient-fitted total joint prosthesis and mandibular advancement on affected side; $\vee$ Bilateral sagittal split osteotomy on a previously placed costochondral graft. 


\begin{tabular}{|c|c|c|c|c|}
\hline $\begin{array}{l}\text { Classification } \\
\text { type }^{\mathrm{a}, \mathrm{b}, \mathrm{c}}\end{array}$ & Therapy & $\begin{array}{l}\text { Percentage } \\
\text { per type } \\
(\%)\end{array}$ & $\begin{array}{l}\text { No. of included } \\
\text { study subjects } \\
\text { (\%) }\end{array}$ & $\begin{array}{l}\text { No. of preceding mandibular } \\
\text { surgery }\end{array}$ \\
\hline \multirow[t]{3}{*}{ Type $\left.\right|^{a}$} & & & $19(33 \%)$ & \\
\hline & $\begin{array}{l}\text { BiMax (Ohtani et } \\
\text { al., 2012; Fattah et } \\
\text { al., 2014) }\end{array}$ & $16 \%$ & $3(5 \%)$ & 0(Ohtani et al., 2012; Fattah et al., 2014) \\
\hline & $\begin{array}{l}\text { LeFort+MDO } \\
\text { (Balaji, 2010; Liu et } \\
\text { al., 2017)a }\end{array}$ & $84 \%$ & $16(28 \%)$ & 0(Balaji, 2010; Liu et al., 2017)a \\
\hline \multirow[t]{3}{*}{ Types I and II ${ }^{\mathrm{b}, \mathrm{c}}$} & & & $7(12 \%)$ & \\
\hline & BiMax & $0 \%$ & $0(0 \%)$ & $N / A$ \\
\hline & $\begin{array}{l}\text { LeFort+MDO } \\
\text { (Monasterio et al., } \\
\text { 1997) }\end{array}$ & $100 \%$ & $7(12 \%)$ & O(Monasterio et al., 1997) \\
\hline \multirow[t]{3}{*}{ Type Ila ${ }^{a}$} & & & $12(21 \%)$ & \\
\hline & $\begin{array}{l}\text { BiMax (Ohtani et } \\
\text { al., 2012; Fattah et } \\
\text { al., 2014) }\end{array}$ & $25 \%$ & $3(5 \%)$ & $\begin{array}{l}1 \text { pt: } 1 \text { x MDO(Ohtani et al., 2012) } \\
1 \text { pt: } 1 \text { x rib graft(Ohtani et al., 2012) }\end{array}$ \\
\hline & $\begin{array}{l}\text { LeFort+MDO } \\
\text { (Luo et al., 2016; } \\
\text { Liu et al., 2017) }\end{array}$ & $75 \%$ & $9(16 \%)$ & $\begin{array}{l}\text { 0(Luo et al., 2016; Liu et al., } \\
\text { 2017) }\end{array}$ \\
\hline \multirow[t]{3}{*}{ Type $11 b^{a}$} & & & $10(18 \%)$ & \\
\hline & $\begin{array}{l}\text { BiMax (Wolford } \\
\text { et al., 2012; Fattah } \\
\text { et al., 2014)ß,y }\end{array}$ & $50 \%$ & $\begin{array}{l}5 \text { (9\%) (Fattah et al., } \\
2014) \beta\end{array}$ & 0 \\
\hline & $\begin{array}{l}\text { LeFort+MDO } \\
\text { (Luo et al., 2016) }\end{array}$ & $50 \%$ & $5(9 \%)$ & 0 \\
\hline \multirow[t]{2}{*}{ Type IIIa,b } & & & $9(16 \%)$ & \\
\hline & $\begin{array}{l}\text { BiMax (Ohtani et } \\
\text { al., 2012; Wolford et } \\
\text { al., 2012; Fattah et } \\
\text { al., 2014) } \beta\end{array}$ & $100 \%$ & $9(16 \%)$ & $\begin{array}{l}1 \text { pt: } 7 x \text { (e.g. rib graft) } \\
\text { 2012) } \\
1 \text { pt: } 12 x \text { (e.gord et al., } \\
\text { al., 2012) }\end{array}$ \\
\hline
\end{tabular}




\begin{tabular}{|c|c|c|c|c|}
\hline & & & & $\begin{array}{c}1 \text { pt: } 6 x \text { (e.g. rib/tibia graft) } \\
\text { al., 2012) } \\
1 \text { pt: } 1 \times \text { sterord et } \\
\text { graft(Wolford et al., 2012) } \\
2 \text { pts: } 1 \text { x rib graft }{ }^{(\text {Fattah et al., 2014) }} \\
1 \text { pt: } 2 x \text { rib graft (Ohtani et al., 2012) }\end{array}$ \\
\hline & LeFort+MDO & $0 \%$ & $0(0 \%)$ & $\mathrm{N} / \mathrm{A}$ \\
\hline
\end{tabular}

Table 4. Overview of classifications and types of reconstruction $(n=38)$

LeFort+MDO: Le Fort I + mandibular distraction osteogenesis; BiMax: BiMaxillary osteotomy; N/A: Not Applicable; MDO: Mandibular Distraction Osteogenesis; SARPE: Surgically-Assisted Rapid Palatal Expansion; pt(s): Patient(s); $x$ : Times of attempts for correction. a Pruzansky-Kaban classification; ${ }^{b}$ Pruzansky classification; ${ }^{c}$ Tabulated as one group. ${ }^{\alpha}$ Followed by a sagittal split osteotomy on the unaffected side as a secondary surgery; ${ }^{\beta}$ Using a patient-fitted total joint prosthesis and mandibular advancement on affected side; $\vee$ One patient following Surgically Assisted Rapid Palatal Expansion. 


\begin{tabular}{|c|c|c|c|}
\hline Citation & Therapy & Analysis method & Timing \\
\hline Liu, H. et al 2017(Liu et al., 2017) & LeFort+MDO ${ }^{\alpha}$ & $\begin{array}{c}\text { Clinical photographs, } \\
\text { cephalometry }\end{array}$ & $\begin{array}{l}\text { Pre-, and post-operative up to } \\
36-56 \text { months }\end{array}$ \\
\hline Luo, E. et al 2016 (Luo et al., 2016) & LeFort+MDO & $\begin{array}{l}\text { Clinical photographs, } \\
\text { Photographic panoramic, } \\
\text { cephalometry }\end{array}$ & $\begin{array}{l}\text { Pre-operative, immediate post- } \\
\text { distraction and } 6 \text { months, } 1,2 \\
\text { and } 4 \text { years post-distraction. }\end{array}$ \\
\hline $\begin{array}{l}\text { Fattah, A. Y. et al. 2014(Fattah et al., } \\
\text { 2014) }\end{array}$ & BiMax & Cephalometry & $\begin{array}{c}\text { Pre-operative, immediate post- } \\
\text { operative and }>1 \text { year post- } \\
\text { operative }\end{array}$ \\
\hline $\begin{array}{l}\text { Wolford, L. M. et al. } 2012^{\text {(Wolford et }} \\
\text { al., 2012) }\end{array}$ & $\mathrm{BiMax}^{\beta}$ & Cephalometry & $\begin{array}{l}\text { Pre-operative, } 5 \text { days and } 76 \\
\text { months post-operative }\end{array}$ \\
\hline $\begin{array}{l}\text { Ohtani, J. et al. } 2012^{\text {(Ohtani et al., }} \\
\text { 2012) }\end{array}$ & BiMax & $\begin{array}{l}\text { Clinical photographs, } \\
\text { cephalometry }\end{array}$ & $\begin{array}{c}\text { Pre-operative and }>1 \text { year post- } \\
\text { operative }\end{array}$ \\
\hline Balaji, S. M. et al. 2010(Balaji, 2010) & LeFort+MDO & $\begin{array}{c}\text { Clinical photographs, } \\
\text { cephalometry, occlusal cant }\end{array}$ & $\begin{array}{c}\text { Pre-, and } 6 \text { months post- } \\
\text { distraction }\end{array}$ \\
\hline $\begin{array}{l}\text { Monasterio, F. O. et al. } \\
\text { 1997(Monasterio et al., 1997) }\end{array}$ & LeFort+MDO & $\begin{array}{c}\text { Photographic panoramic, } \\
\text { Cephalometry }\end{array}$ & $\begin{array}{l}\text { Pre- and post-distraction and } \\
\text { every } 6 \text { months post-distraction }\end{array}$ \\
\hline
\end{tabular}

Table 5. Overview of facial asymmetry analysis methodologies

LeFort+MDO: Le Fort I + mandibular distraction osteogenesis; BiMax: BiMaxillary osteotomy; ${ }^{a}$ Followed by a sagittal split osteotomy on the unaffected side as a secondary surgery; ${ }^{\beta}$ Using a patient-fitted total joint prosthesis and mandibular advancement on affected side. 


\begin{tabular}{|c|c|c|c|c|c|}
\hline Citation & Therapy & $\begin{array}{l}\text { Mandible }(\mathrm{mm}) / \\
\text { ramus height ratio } \\
\text { pre-post }(\%)\end{array}$ & $\begin{array}{l}\text { Maxilla } \\
(\mathrm{mm})\end{array}$ & $\begin{array}{l}\text { Over } \\
\text { correction }\end{array}$ & $\begin{array}{c}\text { Horizontal } \\
\text { occlusal plane } \\
\left(^{\circ}\right)\end{array}$ \\
\hline Liu, H. et al 2017 (Liu et al., 2017) & $\begin{array}{l}\text { LeFort+ } \\
\text { MDO }^{\beta}\end{array}$ & $\mathrm{ND} / 23.8$ & ND & ND & Range $0-2.0$ \\
\hline Luo, E. et al 2016 (Luo et al., 2016) & $\begin{array}{l}\text { LeFort+ } \\
\text { MDO }\end{array}$ & ND/20.5 & ND & ND & Range 1.5-2.0 \\
\hline $\begin{array}{l}\text { Fattah, A. Y. et al. 2014(Fattah et al., } \\
\text { 2014) }\end{array}$ & BiMax & $\begin{array}{l}16.0 \text { (range } 3.0- \\
24.0) / \text { ND }\end{array}$ & $\begin{array}{c}4.4 \\
\text { (range 0- } \\
7.5 \text { ) }\end{array}$ & $6 / 10$ & Improved \\
\hline $\begin{array}{l}\text { Wolford, L. M. et al. } 2012^{\text {(Wolford et }} \\
\text { al., 2012) }\end{array}$ & BiMax $^{\alpha}$ & $\begin{array}{l}17.5 \text { (range 13.2- } \\
22.7) / \mathrm{ND}\end{array}$ & 0.7 & ND & Improved \\
\hline $\begin{array}{l}\text { Ohtani, J. et al. } 2012^{\text {(Ohtani et al., }} \\
\text { 2012) }\end{array}$ & BiMax & ND/ND & 'Minimal' & ND & $2.3(+/-1.4)$ \\
\hline Balaji, S. M. et al. 2010(Balaji, 2010) & $\begin{array}{l}\text { LeFort+ } \\
\text { MDO }\end{array}$ & ND/ND & ND & $2-3 \mathrm{~mm}$ & $\begin{array}{l}\text { Significant } \\
\text { improved }\end{array}$ \\
\hline $\begin{array}{l}\text { Monasterio, F. O. et al. } \\
\text { 1997(Monasterio et al., 1997) }\end{array}$ & $\begin{array}{l}\text { LeFort+ } \\
\text { MDO }\end{array}$ & $\begin{array}{c}16.0 \text { (range 12.0- } \\
19.0 \text { )/ND }\end{array}$ & $\begin{array}{l}\text { range 4- } \\
7\end{array}$ & + & $\begin{array}{l}3 / 7 \mathrm{pts}: 2 \\
4 / 7 \mathrm{pts}: 0\end{array}$ \\
\hline
\end{tabular}

Table 6. Overview of corrections

LeFort+MDO: Le Fort I + mandibular distraction osteogenesis; BiMax: BiMaxillary osteotomy; Mandible: Mandibular elongation; Maxilla: Maxillary downward movement; ND: No Data available; +: Overcorrected (no information available on number of millimeters of the overcorrection); ${ }^{\circ}$ : Asymmetry measured in degrees. ${ }^{\alpha}$ Followed by a sagittal split osteotomy on the unaffected side as a secondary surgery; ${ }^{\beta}$ Using a patient-fitted total joint prosthesis and mandibular advancement on affected side. 


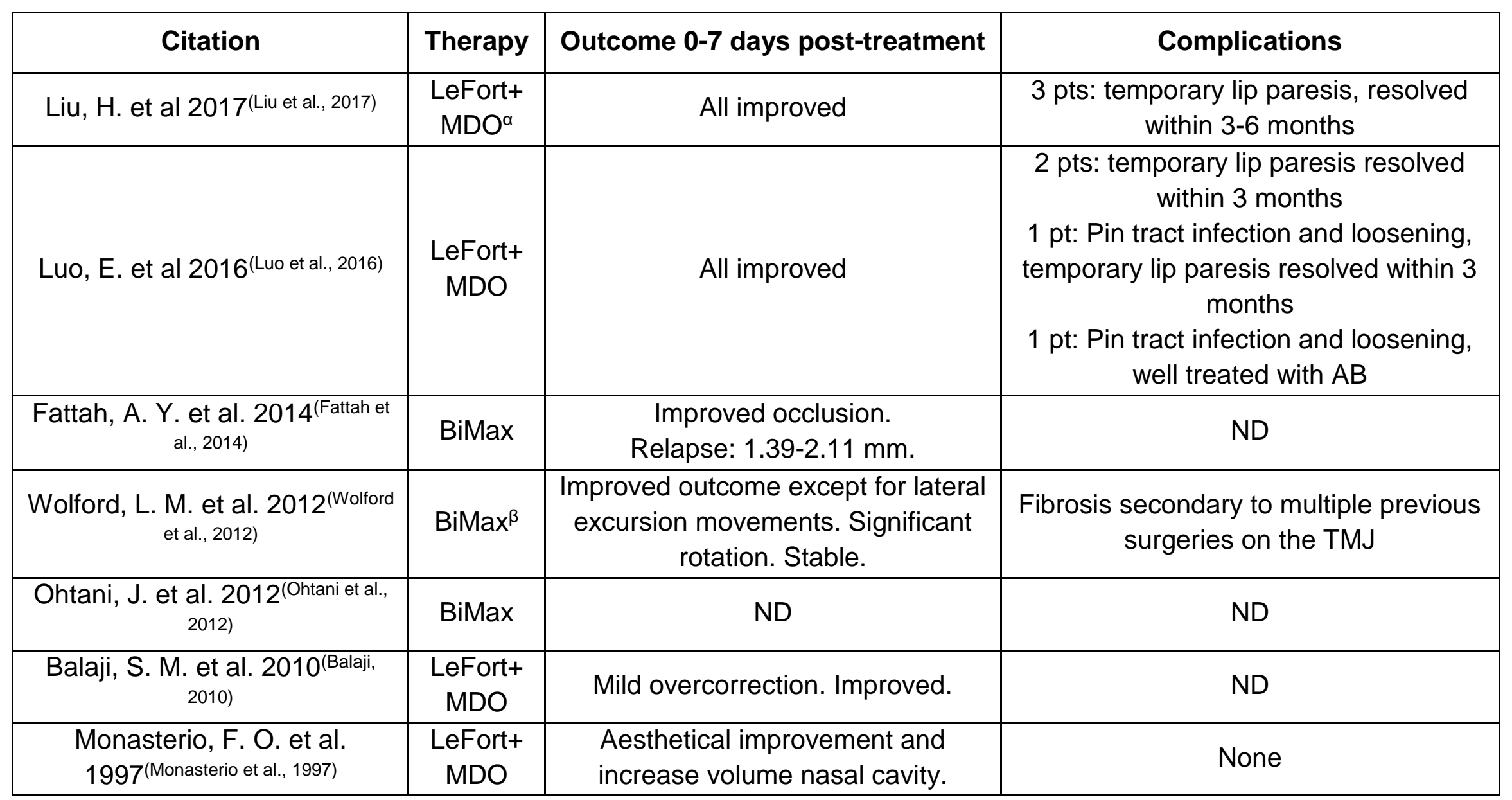

Table 7. Overview of 0-7 days post-treatment outcome and complications

LeFort+MDO: Le Fort I + mandibular distraction osteogenesis; BiMax: BiMaxillary osteotomy; ND: No Data available; pt(s): Patient(s); TMJ: TemporoMandibular Joint. ${ }^{\alpha}$ Followed by a sagittal split osteotomy on the unaffected side as a secondary surgery; ${ }^{\beta}$ Using a patient-fitted total joint prosthesis and mandibular advancement on affected side. 


\begin{tabular}{|c|c|c|c|c|}
\hline Citation & Therapy & $\begin{array}{l}\text { Follow-up } \\
\text { time, months }\end{array}$ & Outcome & Conclusion - Recommendation \\
\hline $\begin{array}{l}\text { Liu, H. et al 2017 (Liu et } \\
\text { al., 2017) }\end{array}$ & LeFort+MDO ${ }^{\alpha}$ & 43.4 & $\begin{array}{l}\text { Significant improved occlusion } \\
\text { cant, horizontal occlusion plane } \\
\text { and facial symmetry. }\end{array}$ & $\begin{array}{c}\text { Two-step procedure: LeFort+MDO } \\
\text { and SSRO as a secondary surgery } \\
\quad+\text { genioplasty, if needed }\end{array}$ \\
\hline $\begin{array}{l}\text { Luo, E. et al 2016 (Luo } \\
\text { et al., 2016) }\end{array}$ & LeFort+MDO & 58.8 & $\begin{array}{l}\text { Minimal relapse of correction in } \\
\text { first } 6 \text { months }\end{array}$ & $\begin{array}{c}\text { Single-stage surgery: } \\
\text { All patients satisfied at latest } \\
\text { control. No secondary surgeries. }\end{array}$ \\
\hline $\begin{array}{l}\text { Fattah, A. Y. et al. } \\
2014 \text { (Fattah et al., 2014) }\end{array}$ & BiMax & 38.4 & $\begin{array}{c}\text { 3/10 improved, } 6 / 10 \\
\text { overcorrected, } 1 \text { worsened. } \\
\text { Minimal non-significant } \\
\text { relapse. }\end{array}$ & $\begin{array}{l}\text { Timing surgery: Skeletal maturity } \\
\text { for stable long-term results while } \\
\text { minimizing morbidity and number } \\
\text { of procedures. }\end{array}$ \\
\hline $\begin{array}{l}\text { Wolford, L. M. et al. } \\
2012^{\text {(Wolford et al., 2012) }}\end{array}$ & BiMax $^{\beta}$ & 75.0 & $\begin{array}{l}\text { Improved incisal opening, } \\
\text { stable maxilla-mandibular } \\
\text { complex, no changes in the } \\
\text { mandible position. No relapse. }\end{array}$ & $\begin{array}{l}\text { Patient-fitted prosthesis use }+ \\
\text { additional secondary procedures in } \\
\text { complex cases. }\end{array}$ \\
\hline $\begin{array}{l}\text { Ohtani, J. et al. } \\
2012^{\text {(Ohtani et al., 2012) }}\end{array}$ & BiMax & 12.0 & $\begin{array}{l}\text { Significant improvement facial } \\
\text { symmetry. Excellent cosmetic } \\
\text { results. }\end{array}$ & $\begin{array}{c}\text { Two-step procedure: Stepwise } \\
\text { interventions with orthodontic } \\
\text { treatment. Ribgraft in severe } \\
\text { cases. } \\
\text { Timing: Skeletal maturity. }\end{array}$ \\
\hline $\begin{array}{c}\text { Balaji, S. M. et al. } \\
2010^{\text {(Balaji, 2010) }}\end{array}$ & LeFort+MDO & 6.0 & $\begin{array}{l}\text { 2-3 mm overcorrection with } \\
\text { stable, predictable results. }\end{array}$ & $\begin{array}{l}\text { Significant angular change lip and } \\
\text { occlusal cant. } 2-3 \mathrm{~mm}\end{array}$ \\
\hline
\end{tabular}




\begin{tabular}{|c|c|c|c|c|}
\hline & & & & $\begin{array}{c}\text { overcorrection gives a better } \\
\text { aesthetical outcome. }\end{array}$ \\
\hline $\begin{array}{l}\text { Monasterio, F. O. et } \\
\text { al. 1997(Monasterio et al., } \\
\text { 1997) }\end{array}$ & LeFort+MDO & 7.0 & Aesthetic improvement. & Timing surgery: pt $>14$ years \\
\hline
\end{tabular}

Table 8. Overview of outcome and recommendation

LeFort+MDO: Le Fort I + mandibular distraction osteogenesis, BiMax: BiMaxillary osteotomy; TMJ:

TemporoMandibular Joint; pt(s): Patient(s). ${ }^{\alpha}$ Followed by a sagittal split osteotomy on the unaffected side as a secondary surgery; ${ }^{\beta}$ Using a patient-fitted total joint prosthesis and mandibular advancement on affected side. 


\begin{tabular}{|c|c|c|}
\hline Citation & Therapy & Soft tissue improvements \\
\hline Liu, H. et al 2017(Liu et al., 2017) & $\begin{array}{l}\text { LeFort+MDO } \\
\text { L }\end{array}$ & Secondary genioplasty \\
\hline Luo, E. et al 2016 (Luo et al., 2016) & LeFort+MDO & $\begin{array}{l}\text { Facial fat grafting, genioplasty, alloplastic } \\
\text { augmentation }\end{array}$ \\
\hline $\begin{array}{l}\text { Fattah, A. Y. et al. 2014(Fattah et al., } \\
\text { 2014) }\end{array}$ & BiMax & $\begin{array}{l}\text { Secondary genioplasty }(n=5) \text {, malar and } \\
\text { mandibular implants }(n=2) \text {. }\end{array}$ \\
\hline $\begin{array}{l}\text { Wolford, L. M. et al. } 2012^{\text {(Wolford et al., }} \\
\text { 2012) }\end{array}$ & BiMax $^{\beta}$ & $\begin{array}{l}\text { Advice: alloplastic/ autogenous implants in } \\
\text { complex cases. }\end{array}$ \\
\hline Ohtani, J. et al. $2012^{\text {(Ohtani et al., 2012) }}$ & BiMax & $\begin{array}{l}\text { Fat augmentation }(n=3) \text {. If needed: } \\
\text { genioplasty, rhinoplasty, muscle flaps and } \\
\text { artificial/ fat fillers. }\end{array}$ \\
\hline Balaji, S. M. et al. $2010^{\text {(Balaji, 2010) }}$ & LeFort+MDO & $\mathrm{N} / \mathrm{A}$ \\
\hline $\begin{array}{l}\text { Monasterio, F. O. et al. } \\
1997^{\text {(Monasterio et al., 1997) }}\end{array}$ & LeFort+MDO & Advice: genioplasty $(n=1)$. \\
\hline
\end{tabular}

Table 9. Overview of soft tissue improvements.

LeFort+MDO: Le Fort I + mandibular distraction osteogenesis, BiMax: BiMaxillary osteotomy; N/A: Not Applicable. ${ }^{\alpha}$ Followed by a sagittal split osteotomy on the unaffected side as a secondary surgery; ${ }^{\beta}$ Using a patient-fitted total joint prosthesis and mandibular advancement on affected side. 
CAPTIONS TO ILLUSTRATIONS

Figure 1. Flowchart of included articles. 
